\title{
Collective Agreements and the Wages of Rubber Tappers in Malaysia, 1954-2003: A Revisit of 'Bad Bargains'
}

\author{
Parthiban S. Gopal ${ }^{a}$ \\ Suresh Narayanan ${ }^{b}$ \\ Universiti Sains Malaysia
}

\begin{abstract}
Drawing on collective agreements pertaining to rubber tappers in the Malaysian plantation sector for the period, 1954-2003, the authors re-examine three conclusions of previous studies: (i) real earnings of tappers had not increased, (ii) the prosperity sharing provision in the agreements was ineffective in passing some of the windfall gains to workers; and (iii) the overall payment scheme, with fixed and flexible components, only benefited employers. These claims, if left to stand without careful re-examination, would represent a serious misinterpretation of facts. Our findings show that overall earnings have kept pace with rising inflation and the prosperity sharing mechanism benefited workers in 43 out of the 46 years since its introduction in 1959. The flexible wage system, while benefitting employers, also protected labour employment in times of rubber price downswings.
\end{abstract}

Keywords: Collective bargaining, daily wage, performance payments, price bonus, rubber plantation

JEL classification: J52, J53, J58

\section{Introduction}

The history of collective bargaining in the commercial plantation sector in Malaysia is a long one. Small unions have tried to champion the cause of labour since the 1900s; however, the first national union representing plantation workers only emerged in 1954 with the formation of the National Union of Plantation Workers (NUPW). Since then it has functioned as the main (and eventually the sole representative) of labour in negotiations with the Malayan Agricultural Producers' Association (MAPA), the only employers' association in the sector.

Over much of the earlier periods of our analysis, rubber remained a key export crop within the plantation sector, and was an important source of agricultural employment. In the 1950s, it was also a major source of export earnings, along with oil palm. However, its prominence began to decline in the mid-1960s as plantations switched from rubber to oil palm when the latter began providing better returns. Between 1965 and 2004, the area devoted to rubber by plantations declined substantially from

a Development Studies Programme, School of Social Sciences, 11800 Universiti Sains Malaysia, Penang, Malaysia. Email: parthi@usm.my

b Economics Programme, School of Social Sciences, 11800 Universiti Sains Malaysia, Penang, Malaysia. Email: nsuresh@usm.my (Corresponding author)

* The authors are grateful to A. Navamukundan of the NUPW and M. Audong of MAPA for useful discussions and for providing us the complete set of the collective agreements used in this paper. We also thank an anonymous referee for constructive suggestions. 
753,000 hectares to 126,500 hectares (Navamukundan \& Geetha, 2003; Gopal, 2006). Rubber output from the plantation sector also contracted between 1979 and 2004, from 618,000 tonnes to 71,200 tonnes and Malaysia lost its place as the world's biggest producer of natural rubber. Employment in the rubber plantation sector followed suite, falling from 128,600 in 1976 to 12,800 workers by 2004 (Gopal, 2006). That the Union prevailed in spite of the unfriendly environment that characterised the latter period merits some discussion; we take up this point later.

Since 1954, 15 wage agreements have been signed on behalf of rubber tappers, with the last agreement examined in this paper being concluded in 2003. In the course of bargaining, the payment scheme for tappers has evolved from a single basic daily rated payment to a hybrid system that combines both fixed and flexible elements. The fixed element provides a guaranteed minimum earning that is invariant to rubber price fluctuations and other factors beyond labour's control, while the flexible elements are incentives that are linked to rubber price and worker productivity.

The collective agreements have been criticised on at least three major grounds. First, it has been argued that they yielded such minimal increases in the wage rate that, once inflation is taken into account, real wages of tappers had either stagnated or become negative (Ramasamy, 1994; Ramachandran, 1994). Second, the prosperity sharing mechanism or price bonus - incorporated in the payment scheme to transfer some of the windfall gains from high rubber prices to labour - has been labelled an illusory concession. This is because the threshold rubber price must cross before the gain is realised was set very high (Ramachandran, 1994). Third, the hybrid payment scheme that combined fixed and flexible elements was seen as conferring benefits only to employers because it gave them the flexibility to keep the basic wage rate rising slowly while offering workers attractive 'flexible' elements that shrunk more than proportionately with a market downturn (Ramachandran, 1994).

These conclusions have never been seriously evaluated; we therefore re-examined the results of all collective agreements from 1954 to 2003 in an attempt to verify the soundness of these findings. We stop our analysis with the 2003 agreement because this agreement changed the payment scheme substantially. For the first time, the Union succeeded in obtaining a guaranteed minimum monthly earning of RM 350.00 (excluding the price bonus and productivity incentive) when, because of yields and/or fewer opportunity days of work, the tapper's basic earnings did not reach at least this level. In a sense, therefore, the Union finally obtained the 'safety net' that it had long sought for, though it did not come in the form of a monthly wage that it had battled for over the years (Gopal, 2006).

\section{Collective Bargaining: Tussle of Unequal Forces}

The rubber sector in Malaysia is characterised by big, privately owned plantations, smaller owner-managed plantations and government land schemes and smallholdings, largely owned and worked upon by the owners themselves. The NUPW's membership and sphere of influence is limited to the big plantations that either belong to MAPA or stay outside it. In relative strength, MAPA with its membership, financial resources and indirect government patronage, comes out well ahead of the NUPW. As of 21 March 
2000, MAPA's membership had stood at 185 companies, controlling 464 plantations with a planted hectarage of 706,019 hectares. In terms of rubber, MAPA plantations accounted for about 62.2 percent of the total planted hectarage under private plantations (Audong and Tan, 2000, p. 43). Despite a decline in power and control over the years, MAPA "plays a dominant role in the industry and the wage system established through negotiations and adjudication with the NUPW is keenly followed and practised by the rest of the industry" (Audong and Tan, 2000, p. 43).

In contrast, the NUPW started in 1954 with just 13 percent of estate workers as members; membership peaked in 1965, when 62 percent were members (Nijhar, 1976, p. 101). However, by 1989, this had dwindled to just 27 percent (Ramachandran, 1994, p. 294) and by 2001 , the membership stood at 37,663 (Navamukundan \& Geetha, 2003, p. 365) or about 16 percent of the total plantation workforce.

The decline in Union membership was largely the result of conversion of plantation land for other uses (such as housing and industrial purposes) and the influx of foreign labour into the plantation sector since the 1980s. In 2001, about 147,510 foreign workers were employed legally in the plantation sector (Jabatan Imigresen Malaysia, 2006). They comprised about 35 percent of the workforce in the sector although the proportion was probably higher if illegal immigrant workers are taken into account. In MAPA plantations, about 43,000 workers or about 40 percent of the 177,662-strong workforce was foreign in 2000 (Audong and Tan, 2000, p. 44). Although the law allows foreign workers to be Union members, an NUPW source claimed that they either choose to be 'free-riders' (since Union negotiated benefits accrue to them as well), or are discouraged from being members by their agents or management. Many estates were also relying on immigrant workers hired as contract workers; in such a situation the contractor determined the payments to workers freeing the estates from such responsibilities. In sum, the large presence of foreign workers further undermined the bargaining power of the Union.

The government also influenced the bargaining equation. Until 1967, it was a neutral party in union-employer negotiations but the threat arising from the Indonesian Confrontation (1963-1966) saw the passing of several acts in the name of national security that severely curtailed the scope for independent negotiations. Compulsory arbitration was forced on both public and private sector unions through a series of regulations that culminated in the 1967 Industrial Relations Act that superseded all previous acts. The Act also created an Industrial Court and the Minister of Labour was given the power to refer an industrial dispute to the Court for final and binding arbitration. This undermined both the scope for collective bargaining and a union's option to call a strike (Nijhar, 1976, pp. 110-111).

Under the current framework in place, collective bargaining is the first step towards achieving an agreement. If this fails, an attempt at conciliation by the Department of Industrial Relations follows. If this too proves fruitless, the matter is referred to the Industrial Court for arbitration. The arbitration process is not only time consuming but its award is final and cannot be challenged, appealed against, reviewed, quashed or called into question in any court of law. It is also legally binding on both parties and covers all affected workers, regardless of whether they are union members or not. The collective agreement remains effective for a minimum period of three years, and continues to be in force until a new agreement is concluded. 
The hope of a neutral government stance in an industrial dispute in the plantation sector was further compromised by the fact that the government has acquired a substantial stake in the industry through agencies such as Permodalan Nasional Berhad (PNB), the national capital corporation, which bought over control of all the major European companies during the 1970 s and 1980 s. Thus, the plantation sector is no longer foreign-dominated as it was in the pre-independence era (Navamukundan \& Geetha, 2003, p. 343). These PNB-owned companies are all members of MAPA, lending the organisation a strength that is not immediately apparent.

The Union is constrained by other considerations as well. Non-union contract workers and cheap immigrant workers from Indonesia and elsewhere have become cheap substitutes for unionised workers. Furthermore, pushing wage costs up will hasten the process of converting rubber into the less labour intensive and more profitable oil palm crop, or for other uses such as property development. In 2000, almost 82 percent of the hectarage under MAPA plantations was already under oil palm (Audong and Tan, 2000, p. 43). Since rubber price is determined in the world market, producers cannot pass wage costs forward to consumers via a price increase.

Well aware of these constraints, the Union has only resorted to strikes infrequently. Instead, it consistently adopted an accommodative approach to collective bargaining, opting to focus on shared goals and a problem solving approach in bargaining. This did not mean that labour and management abandoned their independent agendas or the adversarial-style negotiations (Walton, Cutcher-Gershenfeld, \& Mckersie, 1994); it did create an atmosphere where both parties were anxious to find a mutually acceptable compromise.

This 'moderate' stance of the Union has drawn ridicule from its critics who imply that a more militant posture might have yielded more concessions (Ramasamy, 1994; Ramachandran, 1994). However, to argue that militancy would have worked better is to ignore the lessons of the history of the early trade unions in Malaysia. Given the strategic importance of the rubber industry in the early years, the fragile, newly independent government would not have tolerated any extreme approach to collective bargaining. Whatever gains militancy might have afforded would have been short lived. In fact, Nijhar (1976, pp. 142-143) goes so far as to suggest that the Union would have most certainly been banned well before 1967, like the Communist influenced militant unions that preceded it. Even Stenson (1980, p. 169), a critic of 'moderate' unions, admitted that they did "gain for unionised labour an accepted place within the existing economic order, a seat at negotiating tables, representation on government councils and some improvements in wages and conditions... [T] hey were fostered by government and employers because they facilitated orderly bargaining, minimised wild-cat strikes and countered Communist influence."

\section{Data and Methods}

All the twelve collective agreements and three industrial awards that shaped the payment structure of rubber tappers over 1954-2003 period were used to collate the data on basic daily wage rate, the daily task size and the structure of incentive payments. Earnings per estate worker were computed using data available in the Rubber Statistics 
Handbook (Department of Statistics, various years), while the consumer price index (CPI) data that were used to deflate nominal earnings were derived from the International Financial Statistics Handbook of the International Monetary Fund (IMF, 2001).

The general approach to examining the veracity of the criticisms levelled at the gains secured through an agreement or an award is to first highlight the specific criticism and the context in which it was made, before an evaluation of the merit of the claim is undertaken.

\section{Bad Bargains Revisited}

In the 49 years of collective bargaining between MAPA ${ }^{1}$ and NUPW, the Union succeeded in converting the payment scheme of tappers from a purely daily wage system to a system containing time-based elements (like the daily basic wage rate and outturn payments), performance based elements (such as the productivity incentive, payments for scrap rubber and tapping additional trees), a 'prosperity sharing' element (the price bonus) and other miscellaneous payments. The major criticisms centre on the increases in the daily basic wage rate, the effectiveness of the incentive payments in augmenting earnings and the usefulness of the price bonus as a mechanism of sharing windfall gains. Each of these components is reviewed in turn.

\subsection{The Basic Daily Wage Rate}

Tappers were originally paid a fixed daily wage, for a fixed task and a defined number of working hours per day. In reality, the daily wage rate was not truly fixed because it varied positively with rubber price movements across various pre-determined price zones. After the first collective agreement in 1954, the task size was set at 450 trees per day, with 8 hours per working day. The daily wage was RM1.50 (provided rubber price was between $50-60 \mathrm{sen} / \mathrm{lb}$.). ${ }^{2}$ For every 10 sen increase in rubber price, the wage rate rose by an equal amount, but if rubber price rose by less than 10 sen, the wage rate remained unchanged. By the same token, when the wage rate fell with rubber price, the fall occurred with every 10 sen decrease. When rubber price fell below the minimum threshold (fixed at $50 \mathrm{sen} / \mathrm{lb}$. in the first agreement), the rate had to be renegotiated.

Such an arrangement spread the risk of uncertain prices to tappers without giving them an adequate share in profits. The Union first dented this direct link between price and the basic wage rate in the agreement of 1959. While the basic wage rate was set at RM2.00, when rubber price was between $50-60 \mathrm{sen} / \mathrm{lb}$, it rose to $\mathrm{RM} 2.20$ when the price breached that threshold and remained stable thereafter, regardless of price. Once this concession was obtained, the Union improved on the gain. In 1968, it won a basic wage rate (of RM3.10) that remained stable through all the relevant price zones; this principle has remained till the present day.

1 Between 1954 and 1966, the employers' association was known as the MPIEA, or Malayan Plantation Industries Employers' Association. In 1967, it reorganised itself and became the MAPA. For ease of exposition, we ignore this distinction.

2 Currently (January 2017), one ringgit Malaysia (RM) is about 22 US cents. 
The basic wage was akin to a fixed cost to employers and they resisted dramatic increases in this rate. Nonetheless, creditable gains were made in raising the basic wage rate. Prior to unionisation, the wage rate of a male tapper rose by a mere 28 sen over the 57-year period (from 1884-1941), while the corresponding increase for females was just 24 sen, measured in nominal values (Parmer, 1960, pp. 171 \& 211). In contrast, the 49-year period of union representation saw the basic wage rate rising by RM10.10 (in nominal terms), or a fivefold increase over the rate in 1954. Additionally, the genderbased discrimination in wage rates was eliminated.

The increases in basic daily wage secured by the Union after each negotiation from 1954 to 2003, showed a steady increase, apart from the one-time decline in 1959 (Table 1). Until 1979, the increases were gradual but since then, the rise in the (nominal) wage rate has been relatively rapid. The real wage rate grew as well; the 4.5 percent per annum growth recorded by the nominal rate between 1974 and 2003 was well ahead of the 3.8 percent rate of growth of the consumer price index (CPI) over the same period (Table 2). ${ }^{3}$

Critics of the collective agreements have chosen to focus on the gains in the basic wage rate although it was only one of several components in the payment package. For instance, the 1962 agreement was criticised for providing only a five sen increase in the basic wage rate (Ramasamy, 1994, p. 105), although other gains had been secured. The guaranteed earnings on washed out days, additional payments for applying stimulants and a price bonus were a part of the deal and were potential sources for increasing labour incomes. Furthermore, increases in fringe benefits also helped to secure real earnings. Ramasamy also went on to claim that there had been no increase in the basic wage rate between the collective agreements of 1964 and 1965 when, in fact, no collective agreement was signed in 1965.

The gain made in the basic wage rate in the 1968 collective agreement was similarly dismissed by another scholar on the grounds that for a 55 sen raise in the daily wage rate, between 1964 and 1968, the tapper's daily task size was increased from 450 to 465 trees in low yielding fields and up to a maximum of 600 trees in high yielding fields (Ramachandran, 1994, p. 272).

This was true, although there was no reason to believe that it was beyond the capacity of the average worker. Moreover, the task size has not increased since the 1968 Agreement, suggesting that a maximum had been reached. More importantly, the rate per tree computed in Table 1 shows that although the payment per tree had declined between 1956 and 1959, it remained stable until 1964, and has increased steadily since then. In fact, the rate per tree increased from a little over half-a-sen in 1954 to 2.08 sen a tree by 2003, an almost four-fold increase, despite a dip in the rate in the 1959 agreement.

Turning to the 1976 Agreement, it was lamented that despite a doubling of rubber price and significant inflation it brought only a 40 sen increase in the basic daily rate for tappers over its predecessor, the agreement of 1972 (Ramachandran, 1994, p. 276).

These are continuously compounded growth rates. The lack of CPI data for periods prior to 1971 precludes an assessment of the growth in real wage rate between 1954 and 1970. 
Table 1. Basic daily wage rates and the associated task sizes in collective agreements, 1954-2003

\begin{tabular}{cccc}
\hline Year & $\begin{array}{c}\text { Task size } \\
\text { (trees) }^{\text {a }}\end{array}$ & $\begin{array}{c}\text { Daily basic wage } \\
\text { (RM) }\end{array}$ & $\begin{array}{c}\text { Rate per tree } \\
\text { (sen) }\end{array}$ \\
\hline 1954 & 450 & 2.40 & 0.53 \\
1955 & 450 & 3.00 & 0.67 \\
1956 & 450 & 3.30 & 0.73 \\
1959 & 450 & 2.20 & 0.49 \\
1962 & 450 & $2.25^{\mathrm{b}}$ & 0.50 \\
1964 & 450 & 2.55 & 0.50 \\
1968 & 600 & 3.10 & 0.52 \\
1972 & 600 & $3.20^{\mathrm{c}}$ & 0.53 \\
1976 & 600 & 3.60 & 0.60 \\
1979 & 600 & 4.30 & 0.72 \\
1986 & 600 & 7.90 & 1.32 \\
1990 & 600 & 8.75 & 1.46 \\
1995 & 600 & 10.40 & 1.73 \\
1999 & 600 & 11.50 & 1.92 \\
2003 & 600 & 12.50 & 2.08 \\
\hline
\end{tabular}

Notes: ${ }^{a}$ Refers to maximum task size in high-yielding fields.

${ }^{b}$ Based on prevailing price of 78.2 sen/lb.

c Refers to rate when rubber price exceeds 40 sen (which it did). Otherwise rate was RM3.10.

Source: MAPA/NUPW (various years).

Again, this conclusion was based solely on the basic wage rate, forgetting other gains that were a part and parcel of the agreement. Although the 12 percent increase in the basic wage rate between the 1972 and 1976 agreements was indeed completely swamped by a 40 percent increase in the cost of living, this alone cannot be the basis for dismissing the entire 1976 Agreement as amounting to nothing. A more positive outcome emerges when the overall earnings package is examined. The annual earnings per worker increased by nearly 79 percent between 1972 and 1976 in nominal terms, well ahead of the 41 percent increase in the cost of living (Table 2). Thus, contrary to assertions otherwise, the 1976 Agreement increased real earnings during the period concerned.

The agreement of 1979 was similarly belittled because, although it increased the basic wage from the 1976 figure, the increase was viewed as insufficient to keep up with the consumer price index (CPI) figures of the government (Ramachandran, 1994, p. 276). However, the data at hand suggest otherwise.

The Union gained a 19.4 percent increase in the basic wage rate between 1976 and 1979; this outpaced the 14.5 percent increase in the CPI during the same period, thereby raising the real wage rate. Overall real earnings too, increased during this period. The annual (nominal) earnings per worker rose by 19.7 percent between 1976 and 1979, comfortably ahead of the CPI increase of 14.5 percent. 
Table 2. Increases in the basic wage rate, annual earnings per worker and the CPI between collective bargaining intervals (1972-2003)

\begin{tabular}{rcccccc}
\hline Year & $\begin{array}{c}\text { Daily wage } \\
\text { rate (RM) }\end{array}$ & $\begin{array}{c}\% \\
\text { increase }\end{array}$ & $\begin{array}{c}\text { Nominal annual earnings } \\
\text { per worker (RM) }\end{array}$ & $\begin{array}{c}\% \\
\text { increase }\end{array}$ & CPI & $\begin{array}{c}\% \\
\text { increase }\end{array}$ \\
\hline 1972 & 3.20 & - & 1245 & - & 103 & - \\
1976 & 3.60 & 12.5 & 2222 & 78.5 & 145 & 40.8 \\
1979 & 4.30 & 19.4 & 2659 & 19.7 & 166 & 14.5 \\
1986 & 7.90 & 83.7 & 3389 & 27.5 & 224 & 34.9 \\
1990 & 8.75 & 10.8 & 3789 & 11.8 & 245 & 9.4 \\
1995 & 10.40 & 18.9 & 5279 & 39.3 & 297 & 21.2 \\
1999 & 11.50 & 10.6 & 6218 & 17.8 & 338 & 13.8 \\
2003 & 12.50 & 8.9 & 6352 & 2.2 & 359 & 6.2 \\
\hline
\end{tabular}

Sources: Wage rate data from MAPA/NUPW (various years).

CPI data from IMF (2001).

Earnings Data from Department of Statistics (various years).

More generally, Table 2 shows that out of the seven increases in the basic wage rate negotiated between 1972 and 2003, four exceeded the rate of increase of the CPI, including the last one between 1999 and 2003. When all earnings are included, the record is even better; five out of the seven increases in annual earnings per worker exceeded increases in the CPI. Surprisingly, the increase in earnings between 1999 and 2003 lagged behind the increase in CPI, although real earnings seemed to have recovered significantly by 2004 (a non-collective bargaining year).

The last collective agreement of interest, signed in 2003, saw an important breakthrough. A guaranteed minimum monthly basic wage (earnings) of RM350.00 was obtained, on condition the tapper turns up for work on all days on which work is offered and satisfactorily performs the allotted duties (MAPA/NUPW, 2003, p. 8). Furthermore, the rubber price must be above 160 sen per $\mathrm{kg}$. for this to remain in effect. Thus, after a struggle of more than 40 years, something close to a guaranteed minimum wage was achieved. Although this guaranteed monthly basic wage is still tied to a worker's continued effort, the agreement obliges the employer to pay the tapper no less than RM350.00 a month if the tapper is not provided enough work on account of factors such as inclement weather or other reasons outside the worker's control. This provided the tapper a 'safety net' income.

In order to ensure RM350.00 for 24 days of work (in a month), the basic daily wage was raised to RM12.50 per day per task (of 600 trees), with the usual allowances for smaller tasks necessitated by difficult tapping conditions.

\subsection{Performance-based Payments}

Apart from the basic wage rate, there are two important performance-based incentives - the yield incentive and payment for collecting scrap rubber. The yield incentive was first obtained in the Agreement of 1959, and was called the 'Latex Factor'. It began as a fixed payment for every pound of rubber brought in over and above a pre-determined 
weight, with weights varying by the type of field that was being tapped. The rate of payment was fixed, regardless of rubber price. This structure prevailed until 1968.

The Union successfully argued its case before the Industrial Court for varying the payment for the latex factor - now renamed a 'Yield Incentive' - with rubber price movements. The Industrial Court Award of 1968 not only made the yield incentive payable when the weight of latex brought in by a rubber tapper exceeded a predetermined weight, but allowed the rate itself to rise when rubber price exceeded a stated threshold (and fall when rubber price decreased to below this threshold).

This concession was consolidated in the very next Agreement in 1972. The rubber price threshold when this yield incentive became operative was lowered further. This structure has remained unchanged since then, though the rates payable have been raised over time.

The payment for scrap rubber was another concession wrested in the Agreement of 1959. Again, the rate of payment (for each pound and later kg.) of scrap turned in remained fixed, regardless of rubber price. This principle was changed in the Agreement of 1972 with the scrap rate rising after four lower price zones were crossed initially, and subsequently rising every time two price zones were breached. With the Agreement of 1976, the rate payable increased with the price of rubber across a few lower price zones but became a flat rate afterwards, regardless of further increases in rubber price. Both the structure and rates have remained unchanged since the Award of 1990. Thus, at prices exceeding 190 sen a kg., the payment for scrap remains unchanged at 17 sen per $\mathrm{kg}$. (wet weight).

The yield incentive and the payment for scrap rubber collection are part of the flexible components that critics have argued against. Their usefulness in augmenting the income of a tapper depends not only on the worker's effort, but also on the prevailing rubber price. An examination of the average price of rubber from 1959, when these concessions were first obtained, until 2004, showed that for all but one year (1967), the average annual price of rubber exceeded the prescribed threshold for both the yield and scrap incentives to become operative, often very comfortably (Table 3).

Thus, for 45 out of 46 years, the yield factor and payment for scrap have contributed positively to the annual earnings of the tapper.

\subsection{Prosperity Sharing Mechanism (Price Bonus): A Pie in the Sky?}

The prosperity sharing mechanism is a payment linked to rubber price, not the output of the tapper. This was conceived as a channel for passing some of the windfall gains from rubber price upswings to workers. Originally called the 'Price Element', this concession was also gained in the 1959 Agreement, though it operated with a lag. The price had to breach two price zones before the employer became liable to pay. And the rate payable remained fixed, regardless of how much higher the rubber price rose. These restrictions severely limited the extent of 'prosperity sharing' that could be achieved under this mechanism.

In the subsequent Agreement of 1962, these defects were addressed. Although the price had to breach the first price zone before the payment was made, the rate varied directly with subsequent price zones. 
Parthiban S. Gopal and Suresh Narayanan

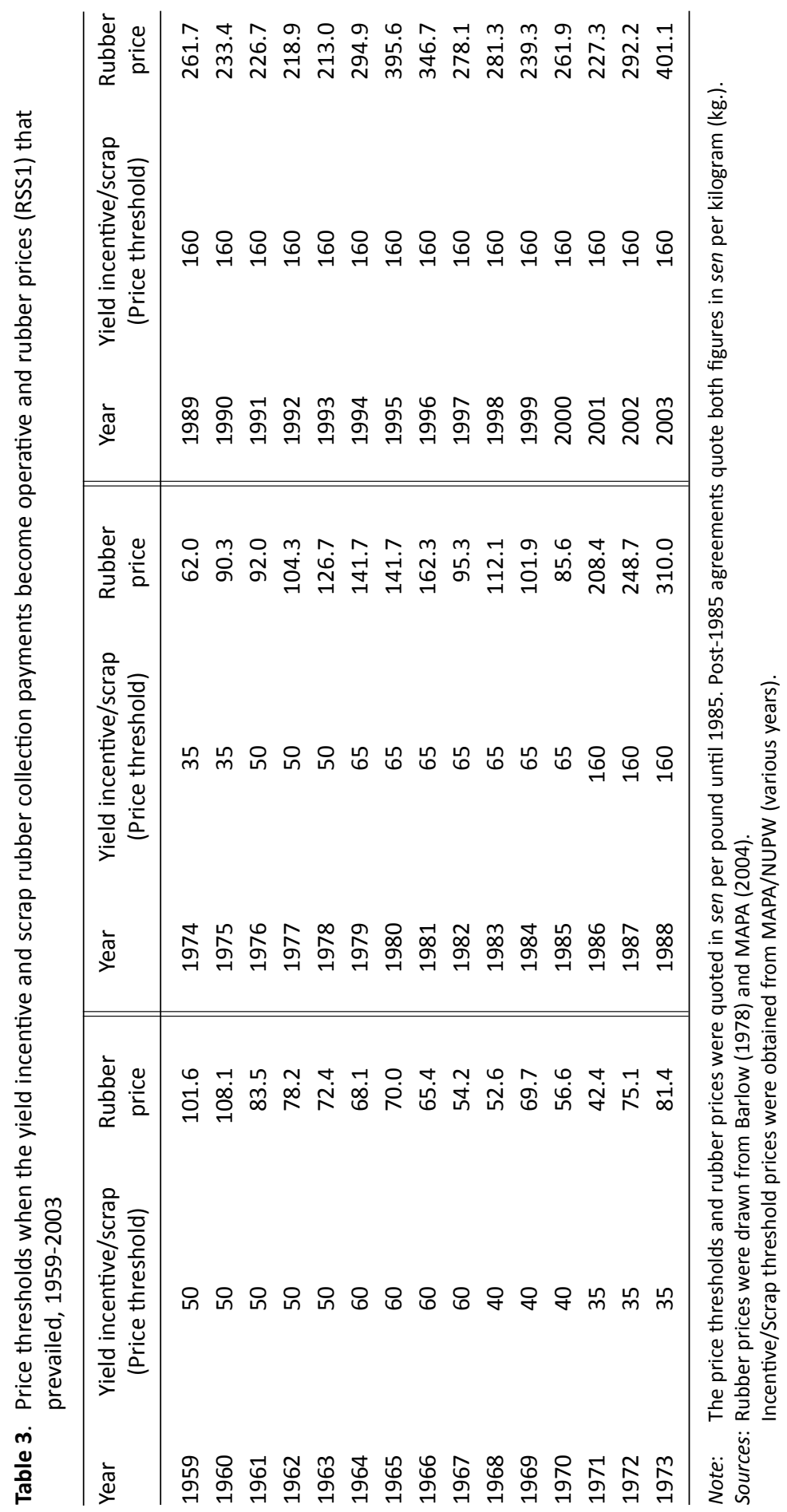


In the 1964 Agreement, it was renamed 'Price Bonus' and a fixed rate of 2 sen was paid for every one sen increase in price, in excess of 70 sen per pound. In the 1968 Award, the bonus was revised and made payable when the price exceeded 50 sen per pound. The principle that the rate of payment would rise with price remained. This basic structure has been retained in subsequent agreements though the rates payable have increased with time.

In the course of criticising the 1968 Agreement, it was opined that price bonus was a 'pie in the sky' because with the constant upward shift of this bonus threshold, workers only receive payment when rubber prices are very high (Ramachandran, 1994, p. 273).

Since its introduction (as the Price Element) in 1959, the threshold when the price bonus becomes payable has actually been lowered as well as raised. It was initially set at 70 sen per pound of rubber and remained unchanged until the Agreement of 1968, when it was lowered to above 50 sen. This remained in place until 1976. The 1976 Agreement raised the threshold to above 55 sen and in 1979 it was raised again to above 65 sen (Table 4).

Despite the changes in the price threshold, over the 21 years that the price bonus has been in effect, the average rubber price exceeded the prescribed threshold in all but three years (1964, 1967 and 1971), giving workers additional income (Table 4). Ramachandran appears to have overlooked this point although he had the rubber price data from 1950 to 1990 (see Ramachandran, 1994, Table 3.2).

More interestingly, from 1980 to 2003, the rubber price well exceeded the threshold, despite the fact that the threshold was set at a new and higher level in 1986. The price bonus was, therefore, not just a 'pie in the sky'; workers seem to have got some of it on their plates as well.

\subsection{Protecting Real Earnings: An Uphill Battle}

Any union is expected to not only seek increases in earnings based on economic factors, but also to nullify the effects of inflation on earnings. And while nominal earnings have elements a union can influence, cost-of-living increases are outside its control. It is therefore an uphill battle for all unions, as it was for NUPW.

In the early years, a cost-of-living (COLA) element was explicitly built in the collective agreements. The COLA allowance was increased based on movements of the official CPI. This kept the spread between nominal and real wages narrow. However, the Industrial award of 1964 'incorporated' the COLA element into the wage rate, making it more difficult to press for separate allowances to account for inflation. This has allowed the gap between real and nominal earnings to widen, with real earnings lagging behind nominal earnings. Furthermore, when nominal earnings fell (because of rubber price downswings), real earnings followed suit but did not always recover with the recovery of nominal earnings.

Until 1964, agreements were also purely voluntary. Either side could call for a fresh one by giving sufficient notice (Nijhar, 1976, pp. 110-111). Between 1954 and 1964, six collective agreements were signed with minimal interference from the government. The Union was able to renegotiate agreements to take advantage of high rubber price and to ameliorate the effects of inflation. 


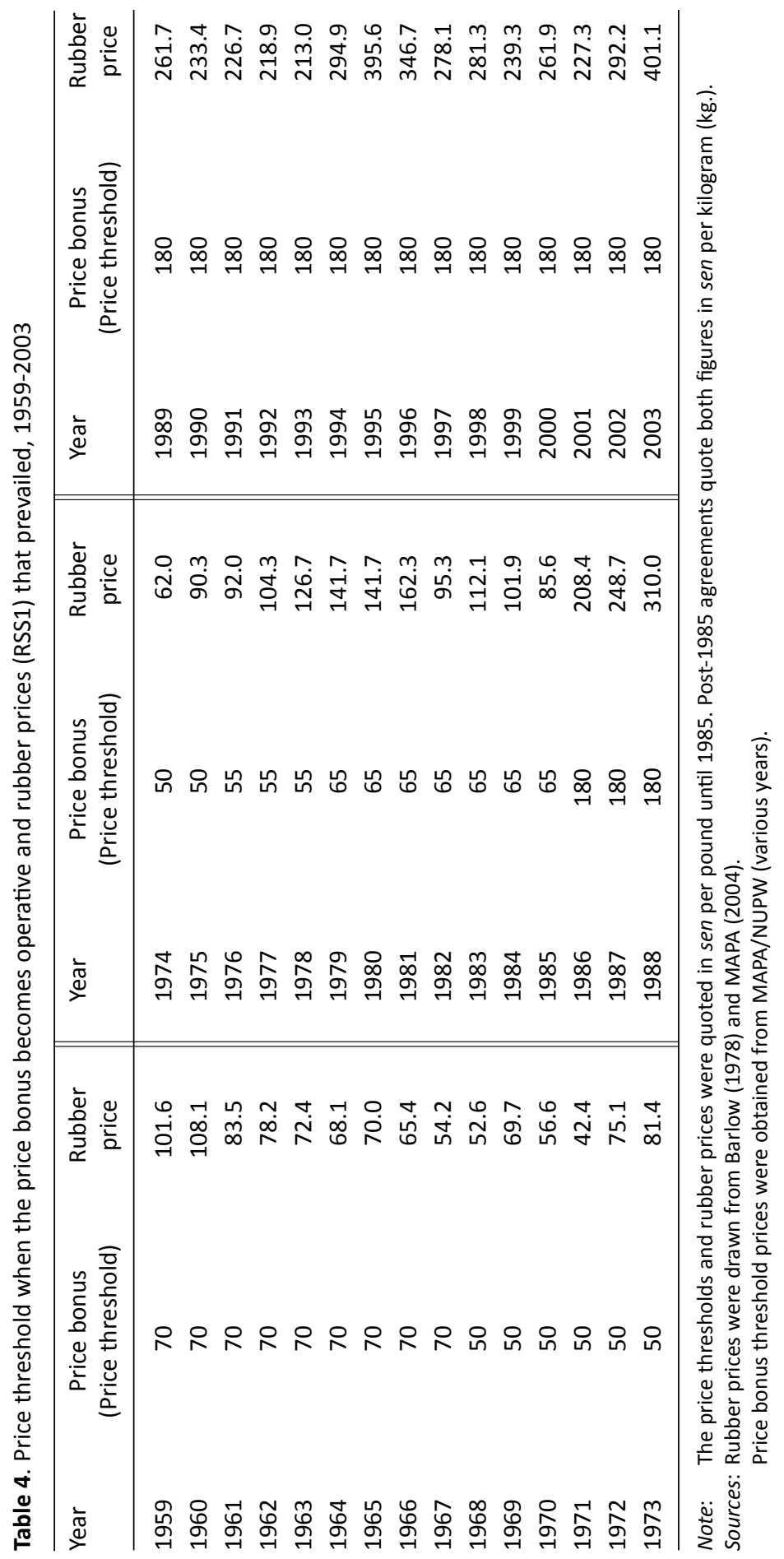


The stipulation, in later years, that collective agreements have a life span of three years and must remain in force after that, until it is superseded by a new agreement, was a serious setback in efforts to preserve real earnings. It was difficult to replace an old agreement exactly when it expired and negotiations to conclude a new one was often prolonged by management, since labour continues to be bound by the old agreement. This is evident from Table 1; there were nine agreements signed after 1964. Of these, only two were concluded with 3-year intervals. Another five were concluded with 4-year intervals, while the remaining two took five and seven years to conclude.

The nominal daily wage rate rises in a step-like fashion, seeing an increase only once in every three years or more (Table 1). In the interim, cost-of-living increases continue to erode the gains, causing the real wage rate to decline, sometimes to negative levels. Wage agreements must wait the full length of at least three years before attempts at restoring real earnings can begin. Table 2 shows this effect for the years when collective agreements were signed.

\subsection{The Hybrid Payment Structure: Does Labour Benefit?}

It has been asserted that the hybrid payment structure worked only to the advantage of the employer because the basic daily wage rate could be kept from rising too rapidly by offering workers attractive 'flexible' elements that shrink more than proportionately with a market downturn (Ramachandran, 1994, p. 296).

In reality, the hybrid payment system also extends some gain to labour by affording job protection to workers during an economic downswing. With tapping costs alone accounting for an estimated 60 percent of plantation costs (Audong and Tan, 2000, p. $53)$, employers naturally seek to reduce costs during a downturn. The Union is therefore forced to choose between maintaining the level of earnings and risking greater unemployment or preserving jobs by accepting a lower level of earnings (Hamermesh \& Rees, 1993, pp. 256-259). In such circumstances, the hybrid payment structure gives some room to the Union to preserve jobs by foregoing some earnings. In fact, available evidence suggests that this indeed occurred. A study that looked at the relationship between price and estate employment between the years 1950-1966, found that employment was hardly affected because the impact of price volatility was absorbed by wage rate changes. A fall in price was followed, after a built-in time lag, by a reduction in wage, leaving total employment unaffected. The study concluded that a basic wage rate that is invariant to rubber price, coupled with additional payments designed to move along with rubber price, enabled workers to enjoy a share of the windfall gain which would otherwise be lost, without seriously jeopardising employment during a downturn (Ariff, 1970, pp. 20-21). The employers' association (MAPA) has corroborated this finding; it has stated that it was able to sustain its plantation workforce during the recession of the 1980s, partly because of the flexibility in the wage system (Audong and Tan, 2000, p. 48).

The unsubstantiated assertion that the flexible elements of the wage shrink more than proportionately with a price downturn is also suspect. An earlier study found that for the period of 1947-58, a 10 percent variation in price induced a 6 percent change in wages (Ariff, 1970, pp. 22-23). A more recent estimate for the period of 1971- 
2004 indicated that a 10 percent change in rubber price results in only a 2.1 percent variation in earnings (Gopal, 2006: 221). This also suggests that collective bargaining has successfully reduced the extent to which earnings react to rubber price volatility.

The other advantage of this hybrid payment scheme is that on occasions when the employer has resisted an increase in the basic wage rate, the Union did not come back empty handed. Concessions were obtained either in the flexible elements or in fringe benefits that contributed to the overall quality of life of workers. The Agreements of 1962, 1964 and 1972 are examples where minimal gains in the basic wage rate were offset by more substantial gains in other payments and benefits. Had the wage system consisted of only the basic wage rate, the Union's ability to wrest concessions would have been severely compromised.

\section{Gains in an Unfavourable Environment?}

As indicated earlier, over the later period stretching roughly from 1965 to 2004, the rubber industry was facing several challenges. Rubber was losing its prominence as a premier export crop, the area devoted to rubber was diminishing, as was the output, and, employment had dropped drastically. That negotiations resulted in concessions to the Union, particularly in such a challenging environment, may appear counter-intuitive. Several factors may have come together to enable the Union's modest successes.

First, the fact that rubber was no longer an attractive option in Malaysia suggests that plantations that continued to persist in the activity were the more cost-efficient ones, as the high cost producers had been weeded out by the competition to survive. The survivors were larger and well organised operations, often with other diversified economic interests. Certainly, most of MAPA members who remained in the rubber industry fitted this description. Thus Union concessions were gained largely from plantations that could afford to concede.

Second, the permanent work force in many estates had been pruned with the diminishing acreage devoted to rubber. Furthermore, in smaller estates field workers were being hired by the principal employer as contract labour through contractors. The wages and other payments of these contract workers were determined by arrangements between the contractor and workers themselves (Lee \& Sivananthiran, 1995). The principal employers are therefore only obliged to grant Union negotiated benefits to the much smaller permanent workforce on their payroll. This reduces considerably the cost associated with implementing the terms of the agreement.

Third, it must be remembered that the Union membership included workers in all plantation agriculture, including the more profitable oil palm industry. And many bigger plantation companies that continued to maintain a presence in the rubber sector also had substantial investments in the more profitable palm oil sector. Surely, employers would have been mindful that maintaining a reasonable bargaining stance in negotiating the wages of workers in one sector would reap positive dividends when discussing wages of workers in the other.

Fourth, while the Union's bargaining strength was apparently weakened by the generally unfriendly attitude of government toward union activism, the Union's national and international connections were strong and the government was well aware of 
this. ${ }^{4}$ In fact, Malaysian unions wielded enough influence in the International Labour Organisation (ILO) for the ILO to send a special representative in 1974 to look at the restrictive labour laws in Malaysia (Morais, 1975, p. 162).

Finally, despite the adversarial attitude adopted by negotiators from the Union and MAPA at the bargaining table, and the hard bargains they drove in the interests of the parties they represent, there was a high level of trust and mutual respect between them both inside and outside the bargaining room. This mutual understanding was built over many years of interaction during which NUPW leaders had shown a remarkable sense of concern not only for their members but for the survival of the rubber industry as a whole. This goodwill was maintained by successive leaders on both sides who remained personal friends despite their professional differences. This is best summed up in the words of a past President of MAPA, who noted that both organisations "have been able to build up, over the years, a lasting and cordial relationship based on mutual understanding and goodwill" (Morais, nd, p. 269).

All these factors taken together probably account for the fair performance of the Union in negotiations in an environment that was unfavourable to the rubber industry as a whole.

\section{Conclusion}

The case that the Union has failed to secure real increases in wages for rubber tappers was built largely on the small gains recorded in the basic daily wage rate in collective agreements. Our reassessment of the data confirms that there were periods when inflation eroded the nominal daily wage rate but this was not always the case. In fact, the struggle to maintain a growing real wage is handicapped by the fact that collective agreements are legally required to remain in force for at least three years.

However, the impact of a collective agreement is better judged by the cumulative effect of all its provisions. From this perspective, collective bargaining outcomes ensured that the overall earnings of rubber tappers kept pace with increases in the cost of living. It is also notable that the Union secured these gains in the face of an increasingly restrictive bargaining environment, declining union membership, and the displacement of its members by foreign workers.

Nonetheless, the task of seeking wage increases based on economic factors and nullifying the effects of inflation on earnings might be too much to place entirely on any union. Low-income earners like rubber tappers (and other workers), whose real incomes are very vulnerable to inflation, should receive an automatic cost of living adjustment, independent of other wage demands, with every wage revision. This should be a

4 The Secretary General of the NUPW was for many years the President of the national labour body, the Malaysian Trade Union Congress (MTUC). He was also the only Asian to head the International Confederation of Free Trade Unions (ICFTU) - a body consisting of 136 organisations in 95 countries representing 85 million workers. He went on to hold the position uncontested for four consecutive terms. He also headed the International Federation of Agricultural and Allied Workers (IFPAAW) and was frequently a member of the Malaysian delegation to the ILO. His personal friendship with all the labour ministers and prime ministers of the country during this period was probably an asset as well (Morais, 1975). 
statutory requirement incorporated in employment law. Alternatively, Malaysia should institute a minimum wage in the agricultural sector as found in neighbouring countries like Thailand, Indonesia and the Philippines. It is regrettable that the Malaysian minimum wage law took effect in 2013 but does not apply in the plantations.

Incentive payments, first introduced in 1959, were found to have contributed positively to labour income in 45 out of the 46 years of its existence. Similarly, the price bonus, contrary to assertions otherwise, has added to the earnings of workers in all but three years since its incorporation in collective agreements in 1959.

In closing, it must be pointed out that despite these efforts, rubber tappers remain one of the poorest paid groups in the economy and the state must be held partly culpable. Apart from restricting trade union activity through legislation, it is an interested party in the wage negotiation process through its indirect ownership of plantations. Furthermore, the state has demonstrated an uncharacteristic apathy in addressing the problem of poverty among plantation workers by pleading that they are located on private properties outside its purview. However, it has also neglected to act in areas where its jurisdiction is undisputed - such as in enforcing its own legislations designed to improve conditions in the plantations.

\section{References}

Ariff, K.A. Mohammad. (1970). The effect of price instability on the employment, wages and profits in the natural rubber industry of West Malaysia. Kajian Ekonomi Malaysia, 7(1), 19-27.

Audong, M., \& Tan, K.E. (2000). Wages and labour scenario in the plantation industry. Kuala Lumpur: Malayan Agricultural Producers' Association.

Barlow, C. (1978). The natural rubber industry: Its development, technology and economy in Malaysia. London: Oxford University Press.

Department of Statistics. (Various years). Rubber Statistics Handbook. Kuala Lumpur: Author.

Gopal, P.S. (2006). The earnings determination mechanism with respect to rubber tappers in Peninsular Malaysia in the pre and post-union eras (Master of Social Sciences [Economics] thesis, Universiti Sains Malaysia, Penang, Malaysia).

Hamermesh, D.S., \& Rees, A. (1993). The economics of work and pay. New York: Harper Collins College Publishers.

IMF. (2001). International Financial Statistics Yearbook. Washington, DC: Author.

Jabatan Imigresen Malaysia. (2006). Taklimat kepada Y.B. Menteri Hal Ehwal dalam Negeri (Briefing to the Minister of Internal Affairs). Kuala Lumpur: Dept. of Immigration (mimeo).

Lee, K.H., \& Sivananthiran, A. (1995). Contract labour in plantations, construction and sawmilling in Malaysia: A survey report. Geneva, Switzerland: International Labour Office.

MAPA. (2004). Annual Report, 2003/2004. Kuala Lumpur: MAPA Headquarters.

MAPA/NUPW. (Various years). Collective Agreements. Petaling Jaya: Plantation House.

Morais, J.V. (1975). Narayanan - The Asian trade union leader. Petaling Jaya: NUPW Sports and Social Club.

Morais, J.V. (no date). P.P. Narayanan: A world trade unionist. Petaling Jaya: Unik Printguide.

Navamukundan, A., \& Geetha, S. (2003). Decent work in agriculture in Malaysia. In D.P.A Naidu \& A. Navamukundan (Eds.), Decent Work in Agriculture in Asia (pp. 328-419). Bangkok: International Labour Organisation.

Nijhar, K.S. (1976). Wage structure: A case study in Malaysia. Kuala Lumpur: Academic Publishers. Parmer, N.J. (1960). Colonial policy and administration: A history of the rubber plantation industry in Malaya, 1910-1941. New York: J.J. Augustine. 
Ramachandran, S. (1994). Indian plantation labour in Malaysia. Kuala Lumpur: S. Abdul Majeed \& Co.

Ramasamy, P. (1994). Plantation labour, unions, capital and the state in Peninsular Malaysia. Kuala Lumpur: Oxford University Press.

Stenson, M.R. (1980). Class, race and colonialism in West Malaysia: The Indian case. Brisbane: University of Queensland Press.

Walton, R.E., Cutcher-Gershonfeld, J.E., \& McKersie, R.B. (1994). Strategic negotiations: A theory of change in management relations. Boston, MA: Harvard Business School Press. 
